\title{
Nature and the Political Ideal of Aristotle
}

\section{La naturaleza y el ideal político de Aristóteles}

\author{
ROAR ANFINSEN \\ Department of Philosophy, UiT The Arctic University of Norway, Norway
}

\begin{abstract}
I argue that we find a «political teleology» in Aristotle which is closely related to his natural teleology. By means of his natural teleology he justifies an ideal political order of domination and subjugation, where most of the population is excluded from citizenship due to their lack of virtue. The lives of the manual workers, whether women, slaves or the free male population, are not valuable according to the higher standards that Aristotle presupposes as necessary for citizenship. The task of the working population is to serve the higher life forms, the life of the ruling class.
\end{abstract}

\author{
KEYWORDS
}

ARISTOTLE, DOMINATION, NATURE, SUBORDINATION, THE BEST STATE

\section{RESUMEN}

En este artículo defiendo que existe una «teleogología política» en Aristóteles que está estrechamente relacionada con su teleología natural. A través de la teleología natural el filósofo justifica un orden político de dominación y subyugacion, en el que la mayor parte de la población queda excluida de la ciudadanía debido a la falta de virtud. Las vidas de los trabajadores manuals, ya sean mujeres, esclavos o miembros masculinos de la población libres, carecen de validez de acuerdo a los criterios más elevados que Aristóteles considera necesarios para la ciudadanía. El objetivo de la población trabajadora es servir a formas más elevadas de existencia, a la vida de la clase dirigente.

\section{PALABRAS CLAVE \\ ARISTÓTELES, DOMINACIÓN, EL MEJOR ESTADO, NATURALEZA, SUBORDINACIÓN}


Aristotle claims that human beings live and should live in politically organized societies because of human nature. And according to Aristotle man isn't just a social animal by nature, but also a political animal. What sounds even stranger, he writes in the Politics that the state (the polis, the city state) is prior by nature to the individual members of the state ( $P o l$ 1253a 20-25). Aristotle compares the polis and its individual members with an organism and its parts, and argues that the organism, the whole, must necessarily be prior to its organs. A human being can exist as a human being without an eye or a hand, but a hand cannot exist as a hand, that is to say have the function of a hand, without the organism. The analogy between the polis and a living being suggests that a human being naturally has a function within the polis, just as an organ naturally has a function within an organism. And it suggests further, as there are different organs in a body, there are different functions in the state. In the Nicomachean Ethics, on the other hand, Aristotle argues that a human being has a function as such, that is a function common to all human beings (EN 1097b22-1098a18). This function belongs to a certain kind of life, a life guided by reason. The function of a good man is to live according to the virtues belonging to this kind of life, that is to say living according to reason in an excellent way. Aristotle cannot, however, be said to have a concept of common human functioning without qualification. There are, in fact, only two kinds of life that qualify for being a proper human life, namely the political and philosophical life. Other kinds of lives have their own standards for doing well and hence their own virtues. These lives are not valuable according to the higher standards, and serve the higher life forms.

As is well known, Aristotle has a teleological view of nature. There is agreement that his teleology applies to living substances, that is, individual living beings. The seed of an apple tree has a kind of inner striving to develop into a grown tree. It thereby realizes or actualizes a form or structure that is naturally given at the outset. The tree then strives towards a goal or an end (telos). There is, however, disagreement about how Aristotle's teleological view is to be further interpreted. One question is whether he holds a teleological view that goes beyond the individual being, a view that includes relations, for instance hierarchical relations, between individual substances and species. I shall argue that Aristotle, at least to a certain degree, has a general teleology. Another question is to what degree his teleology pertains to ethics and politics. That Aristotle's teleology applies to the ethical and political life may on the face of it seem quite obvious. But the extent to which his teleology applies to 
ethics and politics is disputed. I will argue that we find a "political teleology» in Aristotle which is closely related to his natural teleology.

My aim is primarily an historical interpretation. The view I present, however, does not make Aristotle's views on ethics and politics look particularly attractive from a modern point of view.

According to Aristotle, a human being needs to live within a politically organized society in order to function well. As human beings, we have a specific function (ergon) according to our nature (EN 1097b 24-1098 a 20). The function of man is understood as the end or goal (telos) of man. This end is called the supreme good, and that for which all other things exist (Eudemian Ethics 1219a8-12). And it is «the object of the most authoritative of the sciences», which is political science, to investigate what the supreme good of man is ( $E N$ 1094a20-b1). The supreme good is to live in conformity with virtue and hence to be a good man. ${ }^{1}$

According to Fred Miller, even if Aristotle ascribes human beings a function, «he doesn't mean that human beings like tools have instrumental functions» $(1995,348)$. The problem, however, is that those properly belonging to the category of the virtuous, are relatively few. Most human beings don't have the ability to take part in the specific function of man, at least not in the sense of perfecting human nature. Most human beings have a function at a lower level, a function which again is instrumental and is considered as a means to those few who are able to realize the highest human telos.

In the Politics Aristotle raises the question of whether the virtue or goodness of the good man is the same as the virtue or goodness of the citizen $(1276 \mathrm{~b}$ 16-19). He starts with an analogy between a citizen and a sailor, who both have in common that they are members of a community (koinônia):

And although sailors differ from each other in function -one is an oarsman, another helmsman, another look-out man, and another has some other similar special

1 «[...] the Good of man is the active exercise of his soul's faculties in conformity with virtue, or if there be several human excellences or virtues, in conformity with the best and most perfect among them» (NE 1098a16-18). The good of man will also include certain external goods, such as a certain amount of wealth. (The translation of this passage and for the most part is from the Loeb edition, Cambridge, MA and London: Harvard University Press. It will be specified when other translations are used.) 
designation -and so clearly the most exact definition of their excellence will be special to each, yet there will also be a common definition of excellence that will apply alike to all of them; for security in navigation is the business of them all, since each of the sailors aims at that. Similarly, therefore, with the citizens, although they are dissimilar from one another, their business is the security of their community, and this community is the constitution, so that the goodness of a citizen must necessarily be relative to the constitution of the state. If, therefore, there are various forms of constitution, it is clear that there cannot be one single goodness which is the perfect goodness of the good citizen; but when we speak of a good man we mean that he possesses one single goodness, perfect goodness. Hence it is manifestly possible to be a good citizen without possessing the goodness that constitutes a good man ( $\mathrm{Pol} 1276 \mathrm{~b} 22-30)$.

The virtue of a citizen is relative to the constitution of the state. Since there are different constitutions, for instance democracy and aristocracy, there will be different kinds of citizen virtue. A good man, on the other hand, possesses «one single goodness, perfect goodness». The good citizen and the good man cannot therefore be the same, and it is possible to be a good citizen without being a good man. Even if citizen virtue is relative to what kind of institution a citizen belongs to, there is a common characteristic of a good citizen. What makes a citizen good is that he contributes to the «security of the community» (he sôteria tes koinônias). In order to do so a citizen must perform the role he has got.

Again, since the state consists of unlike persons -just as an animal (to take this instance first) consists of soul and body, and a soul of reason and appetite, and a household of husband and wife and [ownership involves] a master and slave, in the same manner a state consists of all of these persons and also of others of different classes in addition to these, -it necessarily follows that the goodness of all the citizens is not one and the same, just as among dancers the skill of a head dancer is not the same as that of a subordinate leader. It is clear then from these considerations that the goodness of a good citizen and that of a good man are not the same in general [...] ( Pol 1277a 6-13).

The citizens have got different roles and functions within a system of division of labor, a system including the social life in general, and the economic, as well as the political, life. Since the roles of the citizens are different, the virtues will accordingly also be different, and so this is another argument that the good citizen and the good man cannot be the same. 
Could it then be the case that a good citizen of a particular sort is the same as the good man? Aristotle's answer to this is that a good ruler is virtuous (agathos) and wise (phronimos). A good man is good only in so far as he is a ruler. The virtues of ruler and ruled are different, and only a leader has got practical wisdom (phronesis). ${ }^{2}$

[...] practical wisdom alone of the virtues is a virtue peculiar to a ruler; for the other virtues seem to be necessary alike for both subjects and rulers to possess, but wisdom assuredly is not a subject's virtue, but only right opinion [...] (Pol 1277b25-29).

The possession of virtue and goodness presupposes a certain function within the society, and a man can be called good only as long as he has the function of a political leader.

Aristotle doesn't seem to presuppose a distinction between the state as political institution on the one hand, and the society and its different social roles and relations on the other. In discussing the citizen's virtue, he focuses on the way the different members of a society perform both their social, productive and political roles. This discussion is, however, illuminating, in that it shows that Aristotle's concept of ethical virtue, the virtue of a good man, is understood as a concept of function within the polis, and more specifically associated with the function of political leadership.

As we have seen, the political science has as its telos the good of man. The good of man is to be a good man, which presupposes the development of practical wisdom, «a virtue peculiar to a ruler». The task of a political leader is to realize a political good, that is to say what is good for the city as a whole. At the beginning of $N E$ Aristotle writes:

For even though it be the case that the Good is the same for the individual and for the state, nevertheless, the good of the state is manifestly a greater and more perfect good, both to attain and to preserve. To secure the good of one person only is better than nothing, but to secure the good of a nation or a state is a nobler and more divine achievement (NE 1094b 7-11).

The good man, then, should pursue the good of the city as whole. It is, however, an important question who belongs to the city. As we shall see, in the best state the major part of the inhabitants, all those who produce the material necessities of life, are excluded from citizenship.

2 For another opinion and a critical discussion of this question, see Keyt 2007. 
The moral qualities of a human being are related to the function he has within the social order and the system of labor in a wide sense. A human being needs to live within a state in order to live a human life. It seems, however, as if only a few are able to develop human qualities to the fullest degree. A question to be discussed (in section VI) is whether the social-political division of labor and accordingly the different levels of human perfection, depend on differences that are naturally given.

\section{III}

Aristotle famously claims that the polis exists by nature. The city-state is said to be the goal (telos) of a process, which starts with the first partnerships, consisting of male and female, and master and slave. Since the first partnerships are natural unions, so also the polis exists by nature. And since the polis is a natural end of the first partnerships, man is «by nature a political animal». The claim that man is a political animal is supported by another argument, namely that man possesses speech or reason $(\log o s)$ : «[...] why man is a political animal in a greater measure than any bee or an gregarious animal is clear. For nature does nothing without purpose; and man alone of the animals possesses speech» (Pol 1253a8-10). Since man has logos, man is said to be more a political animal than any other gregarious animal. This is because speech «is for making clear what is beneficial or harmful, and hence also what is just or unjust». ${ }^{3}$ Aristotle introduces the argument by saying that «nature does nothing pointlessly». Speech, then, is for something, it has a purpose. From the context the ability to speak should be taken as an explanation of why man is a political animal, or more so than the other gregarious animals, an explanation referring to the purpose of language. Language is not only a necessary condition for developing a polis. The ability to speak gives the human development a direction towards a goal. It is the purpose of language to develop fundamental moral and juridical concepts, such as good and bad, just and unjust. The state wouldn't be possible without these concepts, since it is a «partnership» (koinônia) in these concepts that makes (poiei) a household and a polis (Pol 1253a17).

How should we understand his insistence on the naturalness of the polis? Aristotle asserts that the polis exists by nature and is the end of a natural development, which is compared with the development of a man, a horse and a

3 The translation is Reeve's (1998). The Greek preposition epi indicates that speech is for something and has a purpose. 
household. He also claims that the polis belongs to the class of natural things, and that human beings are political animals from nature. Even if Aristotle likens the growth of the polis with individual substances, it is problematic to interpret «exists by nature» in the narrow sense it has in Physics II, what Miller has called the «internal-cause interpretation». The polis cannot be said to grow spontaneously in the same way as a plant or an animal. ${ }^{4}$ With its institutions, presupposing deliberation, division of labor and skills, the polis rather looks like something artificial.

Miller argues that the internal-cause interpretation «contains an important kernel of truth» (Miller 1995, 40), and that the «ultimate basis» for Aristotle's view is human nature, and not the nature of the polis. «His claims about the polis must be understood within his teleological account of human beings as having natural ends». Human beings can achieve «full self-realization» only in the polis (Miller 1995, 41). This interpretation coheres with Aristotle's claim that there is in all human beings an impulse (hormê) towards a polis (1253a 30 ). What then about the objection that the polis seems more like an artificial product than something that develops naturally? Aristotle thinks that there is an important similarity between production and natural growth. They both have a goal, a goal which is given. ${ }^{5}$ According to Saunders and others we should rec-

4 In Physics II 1 Aristotle defines things that exist by nature as things that have «within themselves a principle of movement or change and rest $[\ldots]$ ». An animal or a plant exists by nature in this sense. What exist by nature is distinguished from things that exist due to a craft (technê). Artificially created things don't have an inner principle or impulse (hormê) towards change. A house, for instance, exists due to a cause that is external to the house itself and resides in the builder of the house. A living natural thing grows towards something, and Aristotle uses the concept of nature also to characterize what the thing normally develops into, and which he calls the form of the thing, its eidos or morphe (Phys 193b4). What the thing develops into is the goal (telos) of the movement (194 a30). The goal isn't just the end of the movement, but the thing's purpose and that for which the thing exists. The goal isn't «any kind of termination, but only the best» (194 a30). Aristotle's concept of nature is teleological in the sense that the movement and change of natural things has a goal. The goal of living things is to grow into the form that is already immanent in the thing and which controls the natural development. The goal and form of a thing is called its nature, and since the goal is considered as something good or «the best» for the actual thing, nature is also used in a normative sense.

5 In the Physics (199a17-31) Aristotle writes that animals and plants develop and function in a way that seems to presuppose some kind of reason (nous). Since they cannot be ascribed reason or intelligence, the goal of their activity must be naturally given. Aristotle points out that artificial and natural processes have in common that they both have a purpose or end and that the purpose is given (Phys 199b 27-30). The analogy between art and nature then presupposes that the ends of the different arts are given. In the arts we don't deliberate about the goal, but how to reach it. In EN Aristotle holds that deliberation is «not about ends, but about means» (1112 b12), 
ognize a category of «natural artifacts». Saunders makes a distinction between two senses of «natural». «Nature» in a primary sense describes the impulse to find means to fulfill natural needs. In a secondary sense «nature» denotes «those means themselves», which may include political institutions (Saunders 1995, 63). ${ }^{6}$ There is, then, a natural impulse in human beings to live in a polis, and the polis itself is natural in so far it is created to promote the natural ends of human beings. The polis can be compared to birds' nests and spiders' webs, which are natural constructions and have a natural purpose (199a22-31). ${ }^{7}$ The polis, however, didn't develop without deliberation and art. The impulse (hormê) towards a partnership of this kind «is present in all men by nature; but the man who first united people in such a partnership was the greatest of all benefactors» (1253a 30-31).

Language is, as we have seen, necessary for the existence of a polis, as language is a presupposition for moral and juridical institutions. And the benefactor who first united a population in a polis was a lawgiver. There cannot be a polis without a lawgiver and juridical institutions, since the «virtue of justice is a characteristic of a state; for justice is the arrangement of the association that takes form of a state, and the virtue of justice is a judgment about what is just» (Pol 1253a37-39). The natural impulse to live in a polis exists in everyone, but the ability to organize a polis is not shared by all human beings. The polis comes into existence because of individuals who have the abilities and powers to organize a political process.

The context for the claim that all human beings have a natural impulse to live in a polis is this: Aristotle first argues that the polis is «prior in nature to the household and each of us individually» (Pol 1253a19). This is so because «the whole must necessarily be prior to the part». And «since each individual when separate is not self-sufficient, he must be related to the whole state as other parts are to their whole, [...]» (Pol 1253a 25-27). From this Aristotle concludes that we have from nature an impulse to form a state. That human beings have a natural impulse to form «partnership of this kind» (Pol 1253a 30 ), doesn't just mean that we are social animals. Aristotle obviously thinks that we are political animals in a strict sense. Sometimes, however, he uses the

a view repeated several times. The different arts have in common that «they take some end for granted, and consider how and by what means it can be achieved». This is a view that Aristotle holds about deliberation in general, and so it also pertains to ethical and political deliberation. The interpretation of Aristotle's statements about the relation between deliberation and the goal is disputed, but there is not room on this occasion for a discussion of this question.

6 See also Miller 1995, 41.

7 See Miller 1995, 40 and Saunders 1996, 63. 
word political in a more loose sense. In the History of Animals (488a 8-10) he classifies not only human beings, but also bees, wasps, ants and cranes among «the political animals». They are «political animals» because the members of these species have a common task (ergon), and in this they differ from other gregarious animals. In this context «political animals» means «social animals». In the Politics Aristotle contrasts a desire to live together because we are from nature «political animals», with our seeking to be together because we have a self-interest in doing so. He focuses also in this context on our social nature: «[...] it has been said in our first discourses that man is by nature a political animal; and so even when men have no need of assistance from each other they none the less desire to live together» (Pol 1278b 18-22). We also seek together because we have a «common advantage», but there is further a naturally given desire to live together, which we can call a social desire. But, as already said, «political animal» can also mean political in a stricter sense. If the claim that we are naturally political animals only meant that we want to live together with other human beings, then our natures could be «completely fulfilled within the household» (Kraut 2007, 201).

\section{IV}

We are by nature political animals, and have natural impulses that are peculiar to human beings. We can, however, make distinctions between different levels in the explanation of why we in the end are political animals. By nature we are of course also social animals, sharing impulses for social life with some other kinds of animals. And we have impulses that we share not only with animals in general, but also with plants. Human beings have a natural urge to leave behind an offspring, which explains the union of male and female. What is at work here is some kind of natural principle, a common principle for all the singular substances and species.

According to a widely held view among modern commentators, Aristotle's teleology is restricted in the sense that the telos of an organic being is something internal to the thing and is not a part of a greater whole. There is no kind of natural agent working on an overall level. Balme for instance writes that the «source and nature of animal actions must [...] be explained from the nature of animals», and that Aristotle "provides no evidence [...] for a natural force over and above the individual natures of living things. Although he speaks anthropomorphically of nature choosing and 'doing nothing in vain', he offers no place for an actually hypostatized Dame Nature [...]» (Balme 1987, 278). 
And Miller claims that although «Aristotle frequently speaks of nature in personified terms $[\ldots]$ these expressions are metaphorical. In natural things the end is an innate form or substance which guides the process of development» (Miller 2005, 324).

Aristotle speaks of nature as a person «in countless passages», as Newman formulates it $(1887,19)$. I shall give a few examples of this kind of speak. As we have seen, Aristotle finds in the fact that man alone possesses speech an argument for the claim that man is a political animal to a greater extent than other gregarious animals. The argument seems to be underpinned by the following claim: «For nature, as we declare, does nothing without a purpose (matên)» (Pol 1253a10). And when commenting upon the observation that good parents don't always produce good children, he writes that «nature frequently while intending to do this is unable to bring it about» ( $\mathrm{Pol} 1255 \mathrm{~b} 4)$. Nature sometimes also fails to make the bodies of freemen and slaves different even if this is «what nature wishes» (bouletai phusis). Nature wants to make slaves «strong for necessary service», and freemen "erect and unserviceable for such occupations, but serviceable for a life of citizenship [...]; though as a matter of fact often the very opposite comes about -some persons have the bodies of free men and others the souls [...]» (Pol 1254b27-34). Nature sometimes doesn't work the way it should according to its own standard. Aristotle then clearly uses «nature» in a descriptive-normative sense. Nature intends to develop things according to a certain order, which Aristotle holds as a good order. When nature doesn't work as it should it brings about a result that is considered unnatural. The male is by nature more fitted to command than the female, and exceptions from this natural order is para physis, contrary to nature (Pol 1259b6).

According to Miller, we should understand the expression «nature wishes» and the like metaphorically. It is true that Aristotle doesn't ascribe wishes to nature, as if nature were a human being or some other animal. But this doesn't imply that nature can't be at work somehow above or between the singular substances. And that we should interpret «nature wishes» metaphorically isn't a sufficient argument that teleological processes must be understood as limited to singular substances. We have to ask what the metaphors refer to, and Aristotle obviously does not only refer to what goes on in the singular substances as isolated beings, but also to some relation and order between the individual existing things. ${ }^{8}$ Nature is at work in ways that extend the particular substance,

8 Many commentators (among them Miller 2005, 324, Ross 1995, 71, and Newman $1887,19)$ think that Aristotle in these formulations refers to a principle internal to the particular substance. 
for instance in the way the reproduction of the living substances and so the continuance of all the species is organized..$^{9}$

The first social relations exist, as we have seen, because of necessity. The union of man and woman exists not because of choice (prohairesis), but because of a striving to leave behind an offspring, a kind of natural urge which we also find in animals and plants. On the one hand we can understand the union between man and woman as a purely biological phenomenon. There is at work a natural «force» that leaves no room for choice. On the other hand there also seems to be a normative aspect to this union, as we shall see. The reproduction of a species presupposes a division of the members of the species into two parts and an interaction between these parts. This division cannot be explained in mechanical terms according to Aristotle, who insists that there is a purpose in organizing the reproduction of the species in this particular way. The reproduction of plants and animals, and so the continuity of the species, must ultimately be understood from ontological principles. In the Generation of Animals Aristotle writes:

Of the things which are, some are eternal and divine, others admit alike of being and not-being, and the beautiful and the divine acts always, in virtue of its own nature, as a cause which produces that which is better in the things which admit of it; while that which is not eternal admits of being (and not-being), and of acquiring a share both in the better and the worse; also soul is better than body, and a thing which has soul in it is better than one which has not, in virtue of that soul; and being is better than non-being, and living than non-living. These are the causes on account of which generation of animals take place, because since the nature of a class of this sort is unable to be eternal, that which comes into being is eternal in the manner open to it (GA 731b 25-34).

Earthly bodily beings are not eternal, and have to strive for eternity «in the manner open to it», that is by reproduction. And the different species are divided into two classes «for the sake of generation» (GA 732a 2). But why is there such a division? Why isn't reproduction organized in such a way that each individual living being reproduces itself on its own accord? The reason is

9 For an interpretation more along these lines, see Peter Simpson's comment (1998, 23). 
this: Each individual substance consists of form and matter. The form «is better and more divine in its nature than the matter, and it is better that the superior one should be separated from the inferior one». And so males and females are separated into two classes.

That is why wherever possible and so far as possible the male is separate from the female, since it is something better and more divine in that it is the principle of movement for generated things, while female serves as their matter $(G A 732 \mathrm{~b}$ 6-10).

There is according to Aristotle a normative-ontological principle operative in the reproduction of life. The form (eidos), which defines what a thing is, is the ruling principle. It is also a male principle and the better part. Nature organizes the existing things according to hierarchical normative principles, which includes hierarchical relations between the sexes, between different species, and between humans. There are natural forms of domination extending from the inorganic nature to the lives of plants and animals, and to human lives and political organization.

Authority and subordination are conditions not only inevitable but also expedient; in some cases things are marked out from the moment of birth to rule or to be ruled. And there are many varieties both of rulers and of subjects (and the higher the type of the subjects, the loftier is the nature of the authority exercised over them, for example to control a human being is a higher thing than to tame a wild beast; for the higher the type of the parties to the performance of a function, the higher is the function, and when one party rules and another is ruled, there is a function performed between them) -because in every composite thing, where a plurality of parts, whether continuous or discrete, is combined to make a single common whole, there is always found a ruling and a subject factor, and this characteristic of living things is present in them as an outcome of the whole of nature, since even in things that do not partake of life there is a ruling principle, as in the case of a musical scale (Pol 1254a22-34).

The context for this passage from the Politics is Aristotle's justification of slavery. It is at the same time an expression of a general principle of ruling and being ruled, to archein kai archesthai. ${ }^{10}$ The ruling-subordination relations

10 See M.S. Johnson's comment on this passage $(2005,241)$. Johnson has an extensive treatment of teleology and society (210-246), where he also discusses whether the view that 
include form-matter, soul-body, the rational-irrational part of the soul, manwoman and master-slave.

A domination-subordination principle is also expressed in books 7 and 8 of Aristotle's Politics, where he discusses what he regards as the best constitution. We shall see how the principle, as a whole-part principle, justifies political exclusion of most of the population and political power for a selected group of supremely virtuous men.

From book one of the Politics we know that slaves and women are to be excluded from any kind of constitution as they are considered as mentally inferior owing to their nature. Slaves and women are of course then also excluded from the best city. In addition most of the free male population, the craftsmen, farmers and tradesmen, are denied citizenship and excluded from political participation under the best constitution. What kind of justification is given for the exclusion also of this category?

In book seven of the Politics Aristotle makes a distinction between things that are indispensable for the whole and things that are parts of the whole. This distinction is an important premise in the argument that justifies the exclusion of most of the free male population from the best polis.

Now since, as with other things that are composed according to nature, those things without which the whole could not exist are not parts of the whole composite, it is obvious that in the case of the city too the parts must not be assumed to be whatever it is necessary for cities to have -nor in the case of any other community that forms some single kind of thing. For member of communities must have some single thing that is common and the same, whether they share in it equally or unequally: for example, food, or some expanse of territory, or something else of this sort (1328a21-27). ${ }^{11}$

According to Aristotle, the polis is a natural composite whole, and for such wholes the following principle holds: the fact that something is necessary for

«some humans $[\ldots]$ are naturally subordinate to other humans $[\ldots]$ » is in conflict with the «methodology of teleological explanation» outside the ethical and political writings (s. 243). I cannot discuss these problems here.

11 The translation is from Kraut 1997. 
the existence of such a whole does not in itself make it a part of the whole. The parts or members of the whole, and so also the members of a community, must have one single thing common. To be counted as a part of the best city, one must be able to live according to complete virtue (1328a35-39). As most of the population lack this qualification, they will not be considered as members of the city. Still this majority is necessary for the existence of state.

The tasks and the subsequent classes that are necessary for the existence of a (self-sufficient) polis are: farmers for food production, craftsmen for production of food, military forces for protection against internal and external enemies, priests for service to the divine and then «most necessary of all» the class of politicians, who judge «about what is advantageous and just». ${ }^{12}$ But only the military forces, ${ }^{13}$ the political leaders and the priests, who will be recruited from the group of retired politicians, are counted as parts of the city.

What are the details in the argument for denying workers and farmers citizenship? Aristotle writes that the life of a vulgar craftsman (banausos bios) and the commercial life (bios agoraios) are ignoble and contrary to virtue. As to the farmers, they lack leisure, and preferably they should be slaves. ${ }^{14}$ The argument for the exclusion of the workers and farmers is that they lack the leisure needed for cultivating virtue. There are, however, different opinions as to whether Aristotle also thinks that manual workers are unable to develop virtue also owing to their natural limitations.

As to the exclusion of slaves and women Aristotle argues that even if they have a subordinate function, they are having the best life that is possible according to their nature. In any case, they cannot develop to the highest human level. But can he also say this about the free working population? ${ }^{15}$ Or is their subordinate situation rather accidental and due to bad luck? If so, then this is

12 Aristotle also includes wealth and the wealthy in his list. Wealth is needed for common liturgies, which means «financial support and supervision» of common tasks. Traditionally the liturgies include support of «religious festivals, dramatic choruses, athletic contests and the construction of naval ships» (Kraut 1997, 107). Such tasks are not to be performed by farmers and craftsmen, as they are not counted as parts of the city.

13 The rowers on the naval ships, what he calls the «sailor mob», will be recruited from non citizens, but only citizens will be armed and in control of the ships (1325b5-11).

14 See Pol 1228b38-29a1, 1329a19 and 1330a25-31. See also 1277b33-78a5.

15 Miller writes that Aristotle views «menial workers and artisans as vulgar and slavish, with souls in an unnatural condition and hence incapable of virtue» (Miller 1995, 244), and more generally that «Aristotle's inegalitarianism is based on the alleged natural inferiority of whole classes of persons as defined by nationality, gender and profession» (242). Annas disagrees, and writes that Miller «fails to find ways in which Aristotle clearly claims that the distinction between citizen and worker is based on nature» (Annas 1996, 749). 
something Aristotle seems to be willing to accept. Somebody has to do the necessary work in order that the leading classes can have the leisure required for political offices. The exclusion of most of the population from political participation is condemned by several commentators. ${ }^{16}$ Aristotle, however, doesn't seem to regret the situation, whether the inferior role of the workers is due to chance or nature. He rather shows contempt for the lower classes, the crowd (hoi polloi) as they are called. We should notice some of his harsh formulations.

In $N E$ (1095b14-96a5) Aristotle makes a distinction between three forms of lives, the life of enjoyment, the life of politics and the philosophical life. Most people (hoi polloi) are vulgar and «accordingly are content with the life of enjoyment». They are further characterized as «utterly slavish, by preferring what is only a life for cattle $[\ldots] \gg$. In the last book of the $N E$, in the part regarded as a prologue to the Politics, Aristotle writes:

[...] it is the nature of the many to be amenable to fear but not to a sense of honor, and to abstain from evil not because of its baseness but because of the penalties it entails; since living as they do by passion, they pursue the pleasures akin to their nature, and the things that will procure those pleasures $[\ldots]$ (NE $1179 \mathrm{~b} 11-15) \cdot{ }^{17}$

In the passages quoted we have a characterization of the many, the plurality of the population, as an undifferentiated group. Aristotle says nothing directly about social class or social function. There can, however, be no doubt that this characterization in general pertains to the lower classes and manual workers. And Aristotle also regards manual work as something fitting for slaves: "Those who perform necessary tasks for an individual are slaves; those who perform them for the community are vulgar craftsmen and hired laborers» (1278a11-12).

16 C. C. Taylor writes that «the so-called ideal polis is not a political community at all», but rather «an exploiting elite, a community of free-riders whose ability to pursue the good life is made possible by the willingness of others to forgo that pursuit. Even leaving aside the question of slavery, the 'ideal' polis is thus characterized by systematic injustice» $(1995,250)$.

17 Aristotle discusses here whether we become good due to natural endowment, by habit or through teaching. Even if hoi polloi cannot become virtuous through teaching, this of course doesn't mean that they cannot do so by habit. But still Aristotle seems to underline that there is a natural difference between the many and more noble natures. The many, due to their nature, learn to obey only through punishment and fear and in this sense they are inferior to the noble minority of the population. 
Whether the justification for the exclusion of the free manual workers is based on nature or not, Aristotle accepts that most of the population has an instrumental function and has to serve the ruling class. Even if they are necessary for the existence of the polis, they are not a part of the polis and excluded from citizenship, this as a consequence of his «whole-part principle».

I've said nothing about the more specific political regulations related to the political ideal of Aristotle, but concentrated on the relation between his natural and political teleology. Neither have I said anything about the philosophical life, the highest life form, according to Aristotle. A more detailed account of the relation between the best life, political rule, lawgiving, moral education and the supervision of 'the mores' will not make his political ideals look more attractive. ${ }^{18}$

\section{REFERENCES}

ANNA, JULIA. 1996: «Aristotle on Human Nature and Political Virtue». The Review of Metaphysics. 49, 4:731-753.

BALME, D.M. 1987: «Teleology and necessity». In Philosophical Issues in Aristotle's biology, edited by Allan Gotthelf and James G. Lennox, 275290. Cambridge: Cambridge University Press.

JOHNSON, MONTE RANSOME. 2005: Aristotle on Teleology. Oxford: Clarendon Press.

KEUT, 2007: «The good man and the upright citizen in Aristotle's Ethics and Politics》. In Freedom, Reason and the Polis: Essays in Ancient Greek Political Philosophy, edited by David Keyt and Fred D Miller, Jr., 220-240. Cambridge: Cambridge University Press.

KRAUT, RICHARD. 1997: Aristotle: Politics Books VII and VIII. Translated with commentary. Oxford: Clarendon Press.

KRAUT, RICHARD. 2007: «Nature in Aristotle's Ethics and Politics». In Freedom, Reason and the Polis: Essays in Ancient Greek Political Philosophy, edited by David Keyt and Fred D Miller, Jr., 199-219. Cambridge: Cambridge University Press.

MILLER, FRED D., Jr. 1995: Nature, Justice, and Rights in Aristotle's Politics. Oxford: Clarendon Press.

18 I would like to thank Jan Harald Alnes and Tor Ivar Hanstad for helpful comments on an earlier version of this paper. 
MILLER, FRED D., Jr. 2005: «Naturalism». In Greek and Roman Political Thought, edited by Christopher Rowe and Malcolm Schofield, 321-343. Cambridge: Cambridge University Press.

NEWMAN, W.T. 1887: The Politics of Aristotle. Vol. I. Oxford: Clarendon Press.

PECK, A.L. 1942: Aristotle. Generation of Animals. Cambridge, MA and London: Harvard University Press. (Loeb).

PECK, A.L. 1965: Aristotle. History of Animals I-III. Cambridge, MA and London: Harvard University Press. (Loeb).

RACKHAM, H. 1975: Aristotle. Nichomachean Ethics. Cambridge, MA and London: Harvard University Press. (Loeb).

RACKHAM, H. 1977: Aristotle. Politics. Cambridge, MA and London: Harvard University Press. (Loeb).

RACKHAM, H. 1996: Aristotle. Athenian Constitution. Eudemian Ethics. Virtues and Vices. Cambridge, MA and London: Harvard University Press. (Loeb).

REEVE, C. D. C. 1998: Aristotle: The Politics. With introduction and notes. Indianapolis: Hackett.

ROSS, D. 1995: Aristotle. London and New York: Routledge.

SAUNDERS, TREVOL J. 1995: Aristotle: Politics Books I and II. Translated with commentary. Oxford: Clarendon Press.

SIMPSON, PETER L. PHILLIPS, 1998: A Philosophical Commentary on The Politics of Aristotle. Chapel Hill: University of North Carolina Press.

TAYLOR, C.C. 1995: «Politics». In The Cambridge Companion to Aristotle, edited by Jonathan Barnes, 253-258. Cambridge: Cambridge University Press.

WICKSTEED, PHILIP H. and CONFORD, FRANCIS M. 1993: Aristotle. The Physics, Books I-IV. Cambridge, MA and London: Harvard University Press. (Loeb). 
